\title{
Recent Developments in US Hardwood Lumber Markets and Linkages to Housing Construction
}

\author{
Urs Buehlmann ${ }^{1}$ • Matthew Bumgardner ${ }^{2}$ - Delton Alderman ${ }^{3}$
}

Published online: 22 April 2017

(C) Springer International Publishing AG 2017

\begin{abstract}
Purpose of Review The housing industry has long provided important markets for the higher-value hardwood lumber used in fixtures such as cabinets, flooring, and millwork. These markets have become even more important in the face of the decline in furniture manufacture in the USA. The importance of housing and other construction markets to the US hardwood industry is the focus of the current review.

Recent Findings The housing crisis that began in 2007 (from a construction data perspective) has had a profound impact on the hardwood industry by reducing demand for many products and hardwood industry employment, metrics that recently have started to recover. For higher-value hardwoods, exports have become a critical market in the face of historically low US housing starts. Industrial markets such as pallets and railway ties, traditionally markets for lower-value products, also have increased in relative importance in recent years.
\end{abstract}

This article is part of the Topical Collection on Wood Structure and Function

Urs Buehlmann

buehlmann@gmail.com

Matthew Bumgardner

mbumgardner@fs.fed.us

Delton Alderman

dalderman@fs.fed.us

1 Department of Sustainable Biomaterials, Virginia Tech, 1650 Research Center Drive, Blacksburg, VA 24061, USA

2 Northern Research Station, US Forest Service, 359 Main Road, Delaware, $\mathrm{OH} 43015$, USA

3 Forest Products Laboratory, US Forest Service, 301 Hardwood Lane, Princeton, WV 24740, USA
Summary While housing starts are expected to eventually return to the long-term trend, an analysis of the current marketplace illustrates the importance of the construction markets to the hardwood industry. Potential new markets for emerging products that can make use of hardwoods also are derived from construction-based sectors, so the overall importance of housing and building construction to the hardwood industry is not likely to wane for the foreseeable future.

Keywords Housing starts $\cdot$ Value of construction $\cdot$ Housing fixtures $\cdot$ Hardwood lumber markets $\cdot$ Hardwood industry employment $\cdot$ Sales volume changes

\section{Introduction}

Housing and related construction markets have long been an integral component of the US economy [1] and the wood products market. According to Howard and McKeever [2•], new housing construction was forecast to account for $31 \%$ of all sawn wood consumption (hardwood and softwood, including solid lumber and laminated veneer lumber) and $41 \%$ of all structural panel consumption (including plywood and oriented strandboard) in 2015. Another 23 and 22\%, respectively, of the total volume are consumed by the repair and remodeling sector, underlying the importance of residential construction markets to the wood products industry. Figure 1 shows the value of private construction put in place in the USA since 2002 for major sectors [3]. The size of the overall US construction market can be seen to top $\$ 807$ billion in 2015 . Nonresidential construction, which uses less wood proportionally than the other sectors shown [4], accounted for \$389 billion of the total. Single-family housing construction was larger than nonresidential construction in monetary terms in the years leading up to the housing crisis. Thereafter, the value 
of single-family construction dropped below that of remodeling (or improvements, based on US Census Bureau terminology for the general sector) from 2009 to 2011 during the worst of the housing crisis. One explanation for the relative strength of remodeling expenditures during this period was the large number of foreclosed homes that required maintenance to become marketable [2•]. The sectors and apparent trends shown in Fig. 1 are discussed in this review with an emphasis on some of the implications for the hardwood industry.

Historically, demographic factors have been the most important driver of housing demand, accounting for about twothirds of sustainable or "trend" demand [5]. Macroeconomic factors including interest rates, consumer confidence, income growth, and employment can influence short-term fluctuations around the overall trend [5]. The focus of the current review concerns impacts of US housing markets, including both single-family and multi-family housing, on the primary and secondary hardwood industries. Hardwood lumber, often considered a primary product derived from roundwood or logs, frequently is used in the manufacture of the fixtures of housing, including products such as cabinets, flooring, and millwork or trim (i.e., secondary products). While hardwood lumber is rarely used in the actual construction of housing in the USA, some of the engineered products used in housing construction make use of hardwoods, including oriented strandboard and laminated veneer lumber [6]. The review centers on the importance of housing to the hardwood lumber and lumber-using sectors, as lumber is the most valuable hardwood product emanating from the hardwood forest in aggregate [7].

This paper first describes the current hardwood marketplace and puts the importance of housing markets to the hardwood lumber industry in context. It then discusses the current status of US housing markets and some of the associated impacts on demand for hardwood products. It concludes with a discussion of some innovations and possible opportunities in the construction industry for hardwoods. For example, new products might be poised to make inroads into the nonresidential construction sector, long seen as a segment with great potential for the wood products industry beyond residential construction $[4,8]$.

\section{Importance of Housing to Hardwood Markets}

The importance of housing-related sectors (both single and multi-family, including remodeling) to the US hardwood industry has increased in recent years due to structural shifts in global wood products manufacturing. For hardwoods, sectors related to housing have become crucially important to domestic demand for hardwood lumber given the demise of furniture manufacturing in the USA. As late as the early 1980 s, furniture was the largest single market for US hardwood lumber consumption [7]. Coupled with its use of higher-grade lumber, the furniture sector has long been recognized as critically important to the hardwood industry [9]. However, this position began to change in the late 1980s as imports captured an increasing share of the US furniture market. By 2002, only about $16 \%$ of hardwood lumber production was consumed by the domestic furniture sector (down from a peak of $35 \%$ in 1963), while 33\% went to housing-related markets (including cabinets, millwork, and flooring). Another $37 \%$ was consumed by industrial markets (including pallets and railway ties) [7]. Subsequently, emphasis by the hardwood industry focused more heavily on housing markets but soon encountered the housing crash of 2007-2008. This event had a major impact on the industry. A brief historical series of US hardwood lumber prices, adjusted for inflation, is shown in Fig. 2 [10]. While strong housing markets helped stabilize hardwood lumber prices as the furniture industry declined, prices dropped dramatically with the housing crisis and the associated decline in demand for hardwood products.

One bright spot for hardwood lumber markets during the housing downturn was exports. The value of US hardwood lumber exports reached record levels in 2014 before declining in 2015 (Table 1). However, 2016 was on pace to be similar to, if not greater than, the record year of 2014. The percentage of total hardwood lumber consumption (i.e., consumption being the market for produced hardwood lumber) attributed to exports rose from $8 \%$ in 1991 to $17 \%$ in 2014 [11•]. China has grown to be the largest export destination for US hardwood lumber by a wide margin, amounting to $\$ 1.1$ billion of $\$ 2.3$ billion in total hardwood exports in 2014 (Table 1). China's market share of US hardwood lumber exports has increased from $16 \%$ in 2007 to $47 \%$ in 2015. As late as 2008, Canada was the largest export destination for US hardwood lumber but has since dropped to second behind China. Vietnam had also grown to $\$ 185$ million in export value by 2014 and was the third largest export destination in that year [12].

While Vietnam's appetite for hardwood lumber is unequivocally driven by the country's exported-oriented furniture industry, Chinese demand has been driven by a combination of domestic demand and exports of secondary hardwood products, most notably furniture [13]. Interestingly, of the major hardwood-consuming nations, only China and Vietnam have realized increasing per capita hardwood lumber consumption (defined as lumber production plus lumber imports minus lumber exports) since 1995. Conversely, hardwood lumber consumption per 1000 people in the USA has declined from $104 \mathrm{~m}^{3}$ in 1995 to $49 \mathrm{~m}^{3}$ in 2013 [14]. Overall (hardwood and softwood) US roundwood production also has been shown to be in decline in terms of global market share since 1999 [15•]. One implication of the importance of exports to the US hardwood industry is an increasing interconnectedness to economies and events worldwide [16]. 
Fig. 1 Value of private US construction put in place, 2002 to 2015 [3]

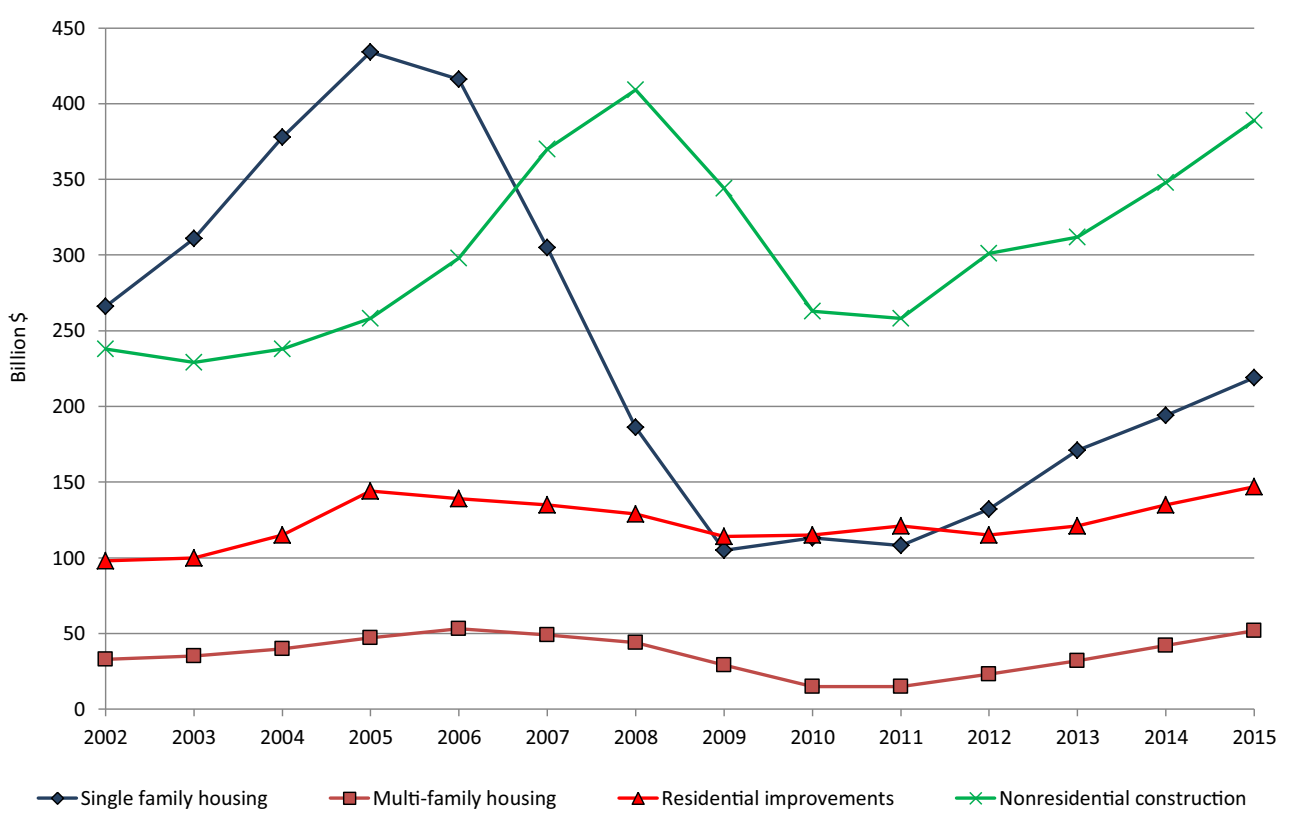

Even though exports now are a critical component of the hardwood market, domestic consumption of higher-value hardwood lumber (i.e., used as an input to downstream processing within the USA) falls mostly to markets related to housing construction and remodeling as the influence of the US furniture market wanes. Combined, these "appearancebased" domestic users (including the remaining furniture production) accounted for $36 \%$ of hardwood lumber consumption in 2014, down from $50 \%$ in 2002 [11•]. Other major uses for hardwood lumber include industrial markets such as pallets, packaging, and railway ties. These markets have historically been an important outlet for the lower-value lumber produced by hardwood sawmills. However, with the decline of the furniture industry followed by the housing crisis, industrial markets have become even more important to hardwood sawmills. The relative consumption of hardwood lumber by these "industrial" products reached $51 \%$ of total consumption in 2014, up from 39\% in 2002 [11•]. Thus, low-grade markets have become the largest domestic consumers of hardwood lumber in the absence of strong housing markets. This illustrates the importance of a healthy housing market for the hardwood industry.

Employment statistics provide another indicator of the importance of housing construction to the hardwood industry. Two useful proxies for hardwood industries directly related to the housing industry are the wood kitchen cabinet and countertop manufacturing industry (North American Industrial Classification System [NAICS] 337110) and the millwork industry (NAICS 32191) [17]. As shown in Fig. 3, single-family housing (the largest residential housing market) starts are highly correlated with employment in both the wood kitchen cabinet and millwork industries [18]. For wood kitchen cabinet industry employment, the Pearson productmoment correlation with single-family housing starts is calculated to be $r=0.76$ from 1990 to 2015. For millwork, the correlation between single-family housing starts and employment was $r=0.90$ for the same period.

\section{Current Trends in the US Housing Market}

Construction-based markets continued their overall growth trend in 2016, as US spending on single-family housing, multi-family housing, remodeling (i.e., residential improvements), and nonresidential construction all increased (Fig. 1). The largest proportional increase was in multifamily housing, which increased by $24 \%$ (in dollar terms) from 2014 to 2015; single-family housing increased by $13 \%$. A single-family house, once excavation begins, counts as a single start; a 100-unit apartment building counts as 100 multi-family starts [19]. The seasonally adjusted annual rate (SAAR) of new single-family housing starts in October 2016 was 869,000 , which represents a $22 \%$ increase over the 714,500 single-family starts in the year 2015 . However, this figure falls far short of the peak number of nearly 1,716,000 in 2005 just prior to the housing crisis [20]. Figure 3 shows the historical significance of the peak year for single-family housing starts (2005), as well as the record low year (2011) that came just 6 years later. However, there have since been 4 years of increases through 2015.

The average size and price of single-family houses have been increasing of late in the USA, and it has been noted that beginner or "starter" home construction has been weaker than population growth would suggest $[21 \bullet]$. Thus, greater activity 
Fig. 2 Aggregate deflated price index $(1967=100)$ for No. 1

Common Appalachian hardwood lumber prices weighted by proportional species representation in the sawtimber inventory, 1967 to 2012 [10]

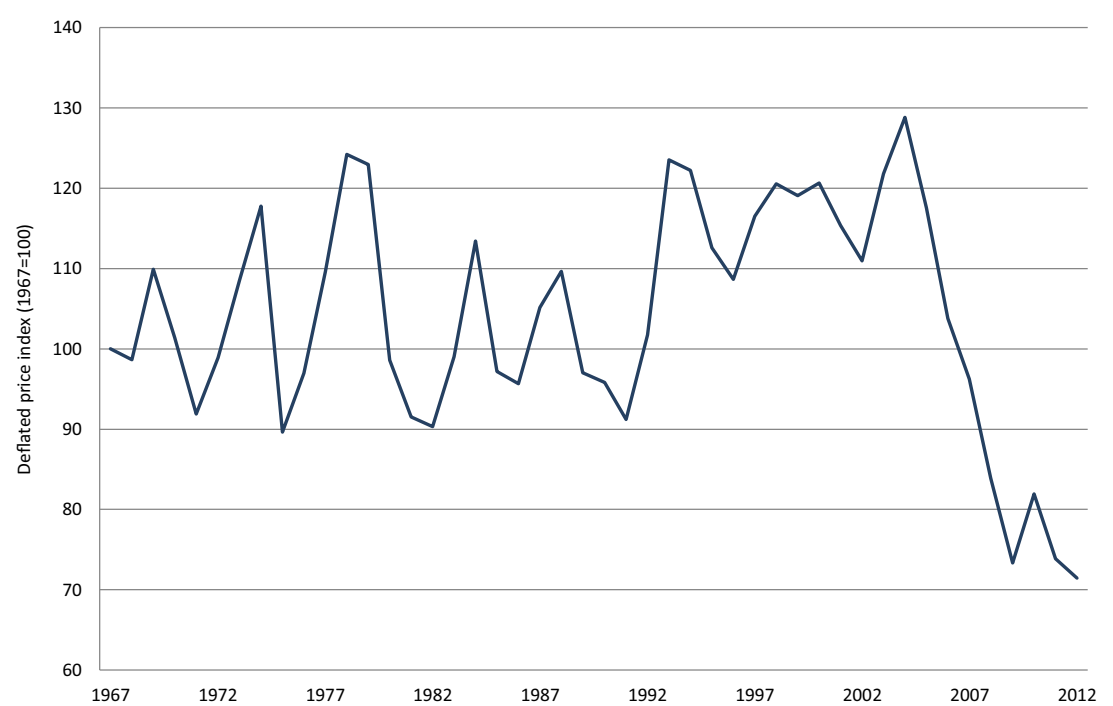

in multi-family housing construction likely reflects, in part, affordability factors for single-family homes (especially for potential first-time buyers) and changing attitudes about home ownership versus renting as a result of the housing crisis [21•]. Although somewhat volatile on a monthly basis [19], multifamily housing starts historically have accounted for about $20 \%$ of total (single family plus multi-family) starts (Table 2). However, this percentage began to increase in 2011 , and by 2015 , multi-family starts represented nearly $36 \%$ of total starts [20].

Because multi-family units are generally less expensive than single-family houses, multi-family's percentage of the total value of new residential construction (single family plus multi-family) was only $19 \%$ in 2015 , but this percentage also has increased since 2011 [3]. Two things are apparent with the data in Table 2: (1) multi-family housing has

Table 1 Top five destinations for US hardwood lumber exports, 2007 to 2015 [12]

\begin{tabular}{llllll}
\hline Year $\quad$ Canada & China & Mexico & Italy $^{\mathrm{a}}$ & Vietnam & $\begin{array}{l}\text { Total } \\
\text { to world }\end{array}$
\end{tabular}

\begin{tabular}{rrrrrrr}
\hline & & \multicolumn{5}{c}{------- \$ million ------- } \\
2007 & 370 & 222 & 98 & 111 & 65 & 1422 \\
2008 & 305 & 187 & 83 & 81 & 60 & 1131 \\
2009 & 200 & 209 & 68 & 69 & 60 & 921 \\
2010 & 266 & 359 & 83 & 109 & 101 & 1322 \\
2011 & 242 & 508 & 82 & 76 & 99 & 1443 \\
2012 & 258 & 603 & 89 & 56 & 131 & 1593 \\
2013 & 263 & 813 & 110 & 57 & 155 & 1859 \\
2014 & 299 & 1096 & 126 & 56 & 185 & 2336 \\
2015 & 250 & 965 & 115 & 43 & 155 & 2060 \\
\hline
\end{tabular}

a Japan and the UK were slightly higher than Italy starting in 2012, dropping Italy to seventh increased proportionally in both number and value during the housing crisis and (2) the value of construction of multifamily units remains lower than single-family houses. This latter point is reflected in the fact that the typical value per single-family start was $\$ 306,508$ in 2015 (derived by dividing total value of single-family construction by total number of single-family starts), compared to $\$ 130,883$ for a multi-family start.

While housing activity of any kind benefits the wood products industry, the proportion of single-family to multi-family starts has implications for the quantity and value of wood products used. For example, in 2001, the construction of single-family housing (excluding fixtures) consumed more than 19 billion board feet of lumber (mostly softwood) compared to 1.7 billion board feet, or $8 \%$, for multi-family construction [5]. That same year, multi-family starts accounted for nearly $21 \%$ of total residential housing starts [20].

\section{Housing Impacts on Secondary Hardwood Markets}

A series of annual studies have been conducted by the authors since 2010 (first assessing data for 2009) to gauge the impacts of housing markets on the secondary hardwood industry, including manufacturers of cabinets (the plurality in each study), millwork, architectural fixtures, and furniture [22, 23]. A summary of some of the results are described below (details of the study methods can be found in the references above). Overall, a trend of improving conditions for surviving companies has been observed.

Analysis of sales performance data over the 7 years of these studies shows a continued gradual increase in the percentage of firms reporting positive changes in year-over-year sales volume, corresponding to gradual improvement in housing 


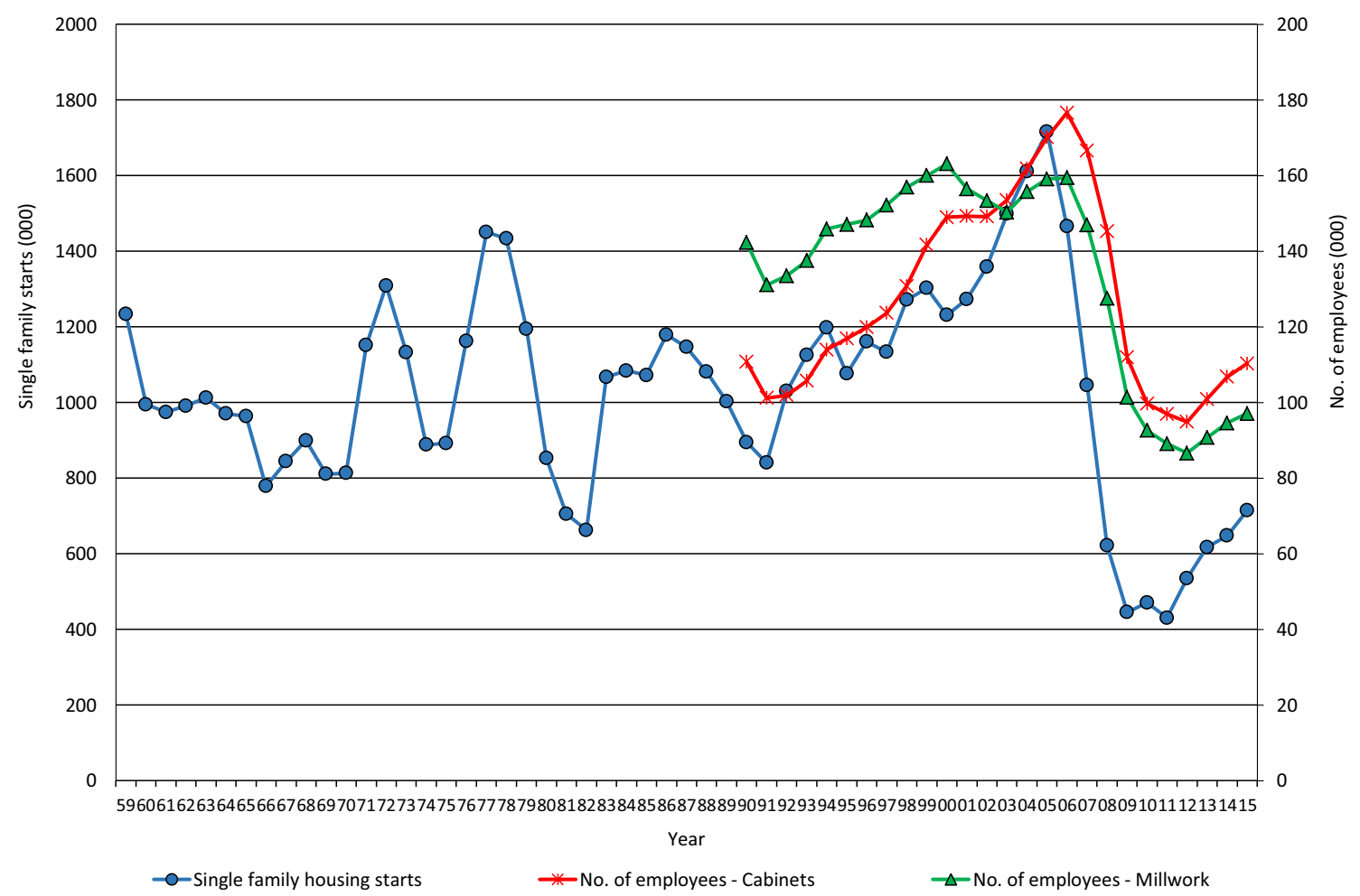

Fig. 3 Single-family housing starts from 1959 to 2015 [20] and number of employees in the US cabinet (NAICS 337121) and millwork (NAICS 32191) industries from 1990 to 2015 [18]. Starting date for all series for the first-year data is available

markets. For example, in 2009, $81 \%$ of respondents reported losing sales volume from the previous year $(60 \%$ reported losing $20 \%$ or more); by 2015 , the proportion reporting a decline in sales volume had decreased to $20 \%$ (Table 3 ). In

Table 2 Multi-family percentage of the US new residential housing market (single family plus multi-family), value of construction [3], and number of starts [20]

\begin{tabular}{lll}
\hline Year & Value of construction & Number of starts \\
\hline & ------ \% ------- & \\
2002 & 11.0 & 20.3 \\
2003 & 10.1 & 18.9 \\
2004 & 9.6 & 17.7 \\
2005 & 9.8 & 17.0 \\
2006 & 11.3 & 18.6 \\
2007 & 13.8 & 22.8 \\
2008 & 19.1 & 31.3 \\
2009 & 21.6 & 19.7 \\
2010 & 11.7 & 19.7 \\
2011 & 12.2 & 29.3 \\
2012 & 14.8 & 31.4 \\
2013 & 15.8 & 33.2 \\
2014 & 17.8 & 35.4 \\
2015 & 19.2 & 35.7 \\
\hline
\end{tabular}

addition, the proportion of respondents in the somewhat better category (sales up by $10 \%$ ) has been increasing or holding steady each year, reaching nearly $30 \%$ in 2015 . Although there was a slight decline in the much better category (sales up by $20 \%$ or more) in 2015 , there was an increase in the unchanged category. The unchanged category has increased each year since 2011, suggesting surviving firms are seeing stabilization in the marketplace [24].

A caveat to the above findings is that the number of cabinet and millwork establishments in the USA has been falling since 2001 (Fig. 4). The rate of decline accelerated during the housing crisis and has leveled off since about 2014. But related to sales volume, this suggests that sales have been improving for surviving companies as others have closed or gone out of business. This trend may turn around in 2016, with preliminary data showing the number of firms increasing. While the number of firms is just beginning to increase (or at least stabilize), Fig. 4 also shows that employment in these sectors has been improving since 2012, which suggests that existing firms have been hiring more employees to meet improving demand for hardwood products.

For those firms indicating a decline in sales volume in any given study year, the possible reasons listed in the surveys have shown a mixture of factors that have decreased and increased in importance (Fig. 5). Perhaps most noteworthy has been a reduction in the number of firms pointing to decline of housing 
Table 3 Year-over-year changes in sales volume in the secondary woodworking industry [23]

\begin{tabular}{|c|c|c|c|c|c|c|c|}
\hline Sales performance category & 2008-2009 & 2009-2010 & 2010-2011 & 2011-2012 & $2012-2013$ & 2013-2014 & $2014-2015$ \\
\hline & & & & - $\%$ - - & & & \\
\hline Much worse (off by $20 \%$ or more) & 60 & 32 & 19 & 15 & 11 & 10 & 8 \\
\hline Somewhat worse (off by $10 \%$ ) & 16 & 12 & 11 & 7 & 7 & 5 & 6 \\
\hline Slightly worse (off by $5 \%$ ) & 5 & 6 & 8 & 9 & 7 & 6 & 6 \\
\hline Slightly better (up by $5 \%$ ) & 5 & 12 & 18 & 16 & 15 & 14 & 15 \\
\hline Somewhat better (up by $10 \%$ ) & 6 & 16 & 19 & 25 & 28 & 28 & 29 \\
\hline Much better (up by $20 \%$ or more) & 3 & 11 & 14 & 17 & 19 & 22 & 19 \\
\hline Unchanged & 6 & 11 & 12 & 11 & 12 & 15 & 17 \\
\hline
\end{tabular}

and remodeling markets as the perceived reasons for declining sales. Nonresidential construction also has declined as a perceived reason for sales volume decline. In the last 2 years, the overall economy, rather than construction markets specifically, was the highest rated cause of sales declines by a wide margin. There also was an upward trend in the importance of the competition-based factors investigated (offshore competition, more domestic competition, and nonwood substitutes) beginning in 2014. As housing markets have continued to improve, it seems that poorly performing firms have begun to see the general economy as the most important factor affecting sales volume. This observation likely can be ascribed, in part, to attribution theory; for example, previous research has shown that poorly performing woodworking firms generally attribute success to external factors (over which they have little or no control) while high-performing firms rate internal factors as the most important to success [25].

\section{Innovations and Opportunities in the Housing Industry}

Future wood products demand depends to a large degree on future housing demand, which is expected to eventually return to long-run averages [15•]. However, advances in housing and other construction sectors also will influence the specific types of hardwood products demanded in the future. While highvalue hardwood logs will continue to be converted to veneer and lumber for many appearance-based uses in homes, much of the hardwood harvest also will be used for industrial purposes like pallets and packaging, engineered wood products, and energy. New products emerging from wood products research and development related directly to housing and construction-based markets that show promise include thermally modified wood products (TMW) and cross-laminated timber (CLT). Both products appear to possess positive

Fig. 4 Employment and number of firms in the wood kitchen cabinet (NIACS 337110) and millwork (NAICS 32191) industries, 2001 to 2015 [18]. Data indexed with $2001=100$ to show trends

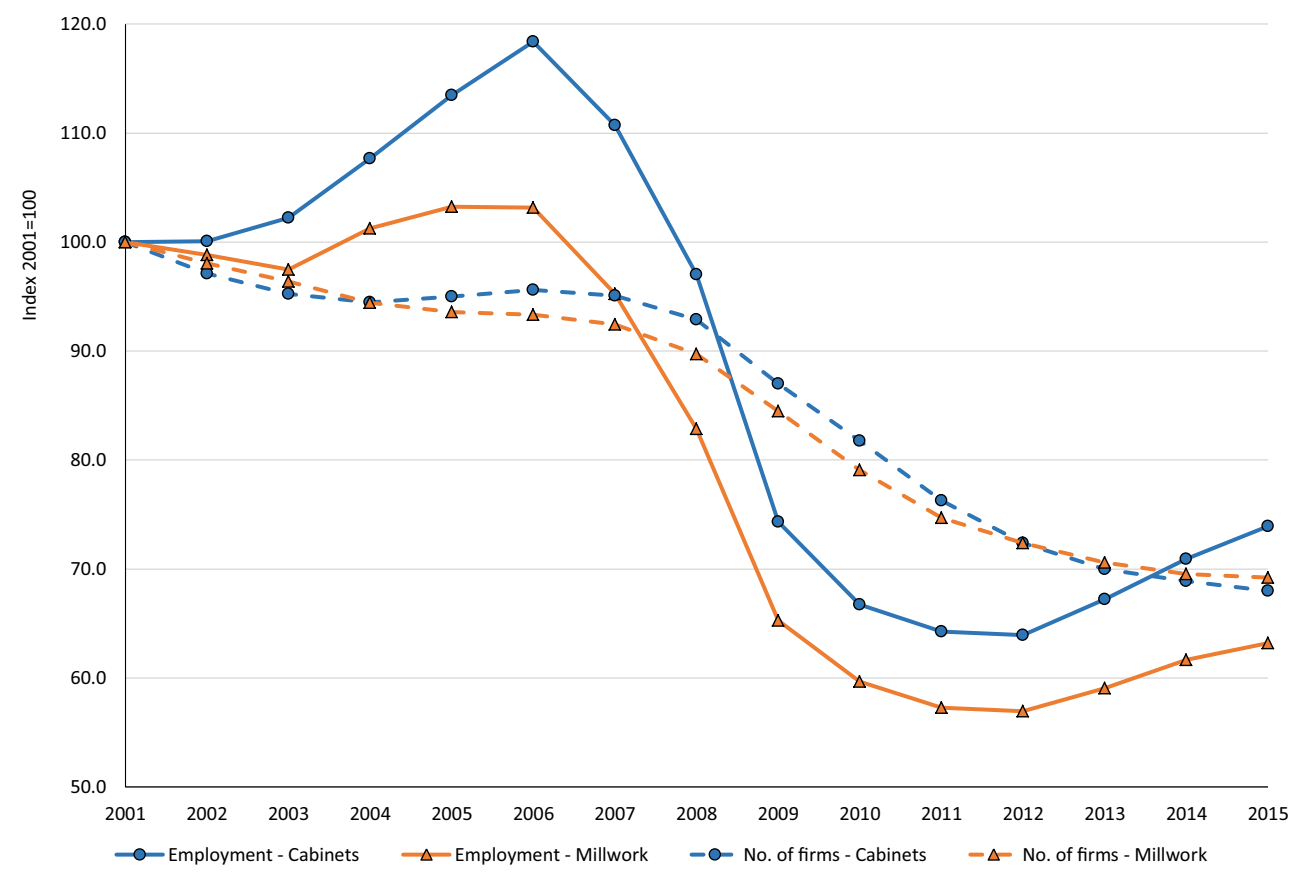




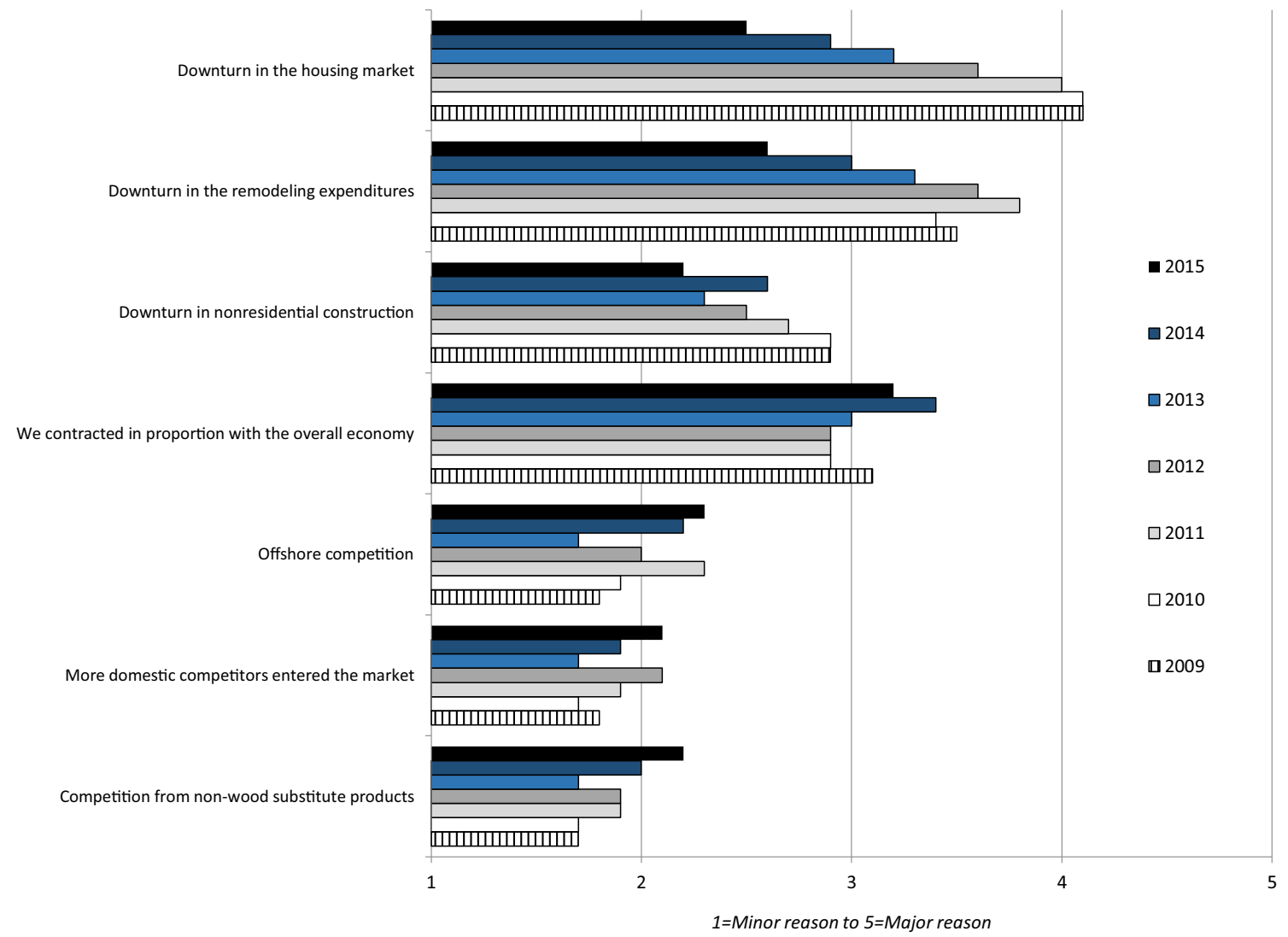

Fig. 5 Perceived reasons for sale volume declines for those firms indicating a decline in each year indicated

properties that affect perceptions of wood among architects and designers of nonresidential buildings, namely, durability and fire resistance [4]. Researchers have long sought opportunities for greater uses of wood in the nonresidential construction sector [8]. As shown in Fig. 1, nonresdiential construction is the largest construction segment by value.

TMW products are made from sawn woods from a variety of hardwood and softwood species that have been subjected to elevated temperatures $\left(160\right.$ to $\left.260^{\circ} \mathrm{C}\right)$ for short periods of time in any number of process conditions related to humidity, use of oils or shielding gases, etc. [26, 27•]. These manufacturing processes alter the chemical and physical properties of the wood, which improves dimensional stability, enhances decay resistance without use of chemicals, and darkens the wood color $[27 \bullet, 28]$. The process reduces the strength and weight properties of wood, which precludes its use in structural applications. However, the properties are ideal for many other building-related uses, including siding, decking, flooring, and millwork. The hardwood species found to be most commonly used in TMW products include ash (Fraxinus spp. L.), yellow poplar (Liriodendron tulipifera L.), red oak (Querces spp. L.), and maple (Acer spp. L.) [27•]. To date, much of the market acceptance for TMW has been in Europe, and much of the US-based production is exported [27•]. TMW markets are expected to improve in the USA, however, as more builders and homeowners become aware of TMW products and their associated benefits [27•, 29].

CLT is an engineered wood product (also referred to as "mass timber") made with sawn wood or engineered lumber laminations arranged into layers that are glued or fastened together at alternating $90^{\circ}$ angles [30]. While softwoods are by far the more commonly used species to date, hardwoods also can be used in the manufacture of CLT, including sawn hardwoods or any number of engineered products that might be made from hardwoods [31]. Production from hardwood is in the early stages of development, and yellow poplar is a US species of focus [32-34]. The thickness of the lumber used can range from 16 to $51 \mathrm{~mm}$ (5/8 to $2 \mathrm{in}$.) and panel sizes can vary by manufacturer or application [35]. The alternating angles are a key difference between CLT and the more traditional product of glulam timber [35], as the alternating layers add rigidity and stability to the CLT panel [31].

One of the main advanatges of CLT is its strength-toweight ratio, which makes it possible to design and build low- and mid-rise structures with wood; this can enable wood products to compete with materials like steel and concrete in some nonresidential applications [30]. Inroads by CLT into nonresidential construction could provide increased demand for wood products, and Crespell and Gagnon [31] have shown that CLT could be cost competitive in a large portion of the 
low- and mid-rise nonresidential market. Other advantages of the massive structure of CLT products include good thermal and sound insultation and good performance under fire [35]. As with TMW, a current disadvantage of CLT is awareness in the marketplace, particularly among engineers who are not trained in the use of wood in nonresidential and taller structures. Similar to TMW, European applications are currently more common than those in the USA, but US interest is growing and code compatibility is an area in need of further development [30, 31, 35, 36].

A major advantage of CLT is that it is prefabricated and thus delivered to the construction site ready to install, which enables shorter and more economical building completion time $[30,31,35]$. Others have noted that panelized and modular housing has replaced manufactured housing (both are alternatives to on-building-site light wood-frame construction) as an efficient mode of building construction [37]. A consideration related to the potential growth of panelized and/or modelized housing going forward is the role of Industry 4.0 or the "fourth industrial evolution [38], p. 411]." Industry 4.0, based on the industrial internet of things [39], describes an increasing reliance on cyber-physical production systems consisting of an "ecosystem of smart factories with intelligent and autonomous shop-floor entities [40], p. 16]." Digitization is bringing vast changes to manufacturing practices everywhere [41], including the US hardwood industries [42]. In fact, a 2015 survey of companies in 26 countries revealed that forest products, paper, and packaging industry leaders estimated that only $38 \%$ of operations and supply chain activities had been digitized, but the expectation was that this level would increase to $72 \%$ in 5 years [43].

This ongoing transformation is challenging to the hardwood industry due to the need to digitize raw material (logs and lumber) information reliably and at low cost [44] when manufacturing traditional solid wood products. Composite products, conversely, are inherently more consistent and uniform in performance [45] and thus likely to play an increasingly important role in housing construction markets. The potential emergence of TMW and CLT as major materials used in the construction and remodeling industries would provide new markets for hardwoods beyond traditional fixture-based product markets.

\section{Conclusions}

Residential construction markets have long been an important component of the overall market for hardwood lumber. Hardwoods are well suited for the manufacture of products such as cabinets, flooring, trim, and other housing fixtures where appearance is of prime importance. Similarly, the furniture industry has historically been of critical importance to the hardwood industry, but structural shifts in global manufacturing have, to a large extent, removed wood furniture manufacturing from the USA. Within this context, housing markets have become even more important to demand for higher-grade US hardwoods. However, industrial markets (pallets and railway ties) have fared better than appearancebased markets during the housing crisis that began in late 2007 , and now account for about half of US hardwood lumber consumption.

The most important market for appearance grade lumber through the housing downturn and the following years has been exports. US exports in 2015 had increased twofold since 2009 and were on pace to set a record value in 2016. Nearly half of US exports today are shipped to China. Canada, Vietnam, Mexico, and several European nations also are important markets for US hardwoods. One implication of the importance of exports is that the US hardwood industry is increasingly interconnected to global economies and events, and the export market helps diversify hardwood markets beyond domestic housing markets.

Housing construction has improved since 2011, registering four consecutive years of increasing single-family housing starts. With this increase in housing construction has come improvement in secondary hardwood manufacturing employment. However, the recovery has been gradual and starts remain well below the peak year of 2005. In addition, there has been a shift to more multi-family starts relative to singlefamily starts. This shift has implications for solid hardwood demand, as more and higher-value fixtures are generally used in single-family construction.

Per capita hardwood lumber consumption has been declining in the USA since 1995. Furthermore, the USA is losing global market share in overall (hardwood and softwood) roundwood production, due in part to offshoring in sectors such as paper and furniture. Increasingly, healthy housing markets are important to generating demand for the highervalue products derived from the hardwood forests of the USA and to employment in many secondary woodworking industries throughout the nation. Likewise, emerging new products such as TMW and CLT appear poised to increase demand for hardwoods, especially in conjunction with healthy construction-based markets.

\section{Compliance with Ethical Standards}

Conflict of Interest Drs. Buehlmann, Bumgardner, Alderman have no conflicts of interests to declare.

Human and Animal Rights and Informed Consent This article does not contain any studies with human or animal subjects performed by any of the authors. 


\section{References}

Papers of particular interest, published recently, have been highlighted as:

- Of importance

1. Leamer EE. Housing is the business cycle. National Bureau of Economic Research. 2007; Working Paper 13428. 72 pp.

2. Howard JL, McKeever DB. U.S. forest products annual market review and prospects, 2011-2015. USDA For Serv Res Pap FPL$\mathrm{RN}-0336,2015,11 \mathrm{pp}$. This paper, in addition to providing commentary and analysis concerning economic conditions for wood products, provides current market share data for all major wood products across all major industries and sectors.

3. U.S. Census Bureau. Construction spending, historical value put in place. 2016; Retrieved from http://www.census.gov/construction/ c30/historical_data.html

4. Robichaud F, Kozak R, Richelieu A. Wood use in nonresidential construction: a case for communication with architects. For Prod J. 2009;59(1/2):57-65.

5. Schuler A, Adair C. Demographics, the housing market, and demand for building materials. For Prod J. 2003;53(5):8-17.

6. Alderman DR, Bumgardner MS, Baumgras JE. An assessment of the red maple resource in the northeastern United States. North J Appl For. 2005;22(3):181-9.

7. Luppold WG, Bumgardner MS. Forty years of hardwood lumber consumption: 1963 to 2002. For Prod J. 2008;58(5):7-12.

8. O'Connor J, Kozak R, Gaston C, Fell D. Wood use in nonresidential buildings: opportunities and barriers. For Prod J. 2004;54(3): 19-28.

9. Sinclair SA. Forest products marketing. McGraw-Hill, 1992, 403 pp.

10. Luppold WG, Bumgardner M, McConnell TE. Impacts of changing hardwood lumber consumption and price on stumpage and sawlog prices in Ohio. For Sci. 2014;60(5):994-9.

11. Luppold WG, Bumgardner MS. US hardwood lumber consumption and international trade from 1991 to 2014. Wood Fiber Sci. 2016;48(3):162-70. This paper provides recent and historical estimates of US hardwood lumber consumption by major market segments (appearance-based and industrial) and describes the importance of hardwood trade (net exports) to the US hardwood industry. The importance of the housing crisis to hardwood lumber demand is illustrated.

12. USDA, Foreign Agricultural Service. Global Agricultural Trade System (GATS) online. 2016; Retrieved from https://apps.fas. usda.gov/gats/default.aspx

13. Luppold WG, Bumgardner MS. Thirty-nine years of U.S. wood furniture importing: sources and products. Bioresources. 2011;6(4):4895-908.

14. Luppold WG, Bumgardner MS. Examination of worldwide hardwood lumber production, trade, and apparent consumption: 19952013. Wood Fiber Sci. 2015;47(3):283-94.

15. Wear DN, Prestemon JP, Foster MO. US forest products in the global economy. J For. 2016;114(4):483-93. This paper shows US industrial roundwood consumption in a global context, discussing different cyclical (e.g., housing) and long-run trends (offshore competition) affecting US production. It is concluded that cyclical improvement in housing will benefit US production but offshoring in some major sectors will prevent the US from returning to the peak production levels of the late 1990s.

16. Luppold WG and Bumgardner $\mathrm{M}$. The international hardwood lumber market and potential impacts on your bottom line. Pallet Enterprise. 2014; December:20,22,24-5.

17. U.S. Census Bureau. North American Industrial Classification System. 2016; Retrieved from http://www.census.gov/eos/www/naics/
18. USDL, Bureau of Labor Statistics. Quarterly census of employment and wages. 2016; Retrieved from http://data.bls.gov/cgi-bin/dsrv?en

19. Carnes WS, Slifer SD. The atlas of economic indicators. Harper Business, 1991, 232 pp.

20. U.S. Census Bureau. New residential construction, historical data. 2016; Retrieved from http://www.census.gov/construction/nrc/ historical data/index.html

21. Alderman D. Housing and construction. Forest Products Annual Market Review 2015-2016. UNECE/FAO publication ECE/TIM/ $\mathrm{SP} / 40 ; 2016$. p. 123-131. This paper is the latest in an annual review of developments in housing and construction markets in Europe, the Russian Federation, and North America. The paper provides recent statistics and outlooks for these markets, which have important implications for wood products markets.

22. Bumgardner MS, Buehlmann U, Schuler AT, Koenig KM. Impacts of construction markets on firm performance and behaviors in the secondary woodworking industry, 2010-2013. In Groninger JW, Holzmueller EJ, Nielsen CK, Dey DC, editors. Proceedings of the $19^{\text {th }}$ Central Hardwood Forest Conference. USDA For Ser Gen Tech Rep NRS-P-142; 2014. p. 312-321.

23. Bumgardner M, Buehlmann U, Koenig K. Investment activities in the U.S. secondary woodworking industry. In Kabrick JM, Dey DC, Knapp BO, Larsen DR, Shifley SR, Stelzer HE, editors. Proceedings of the $20^{\text {th }}$ Central Hardwood Forest Conference. USDA For Ser Gen Tech Rep NRS-P-167; 2017. p 184-191.

24. Buehlmann U, Bumgardner M, Koenig K. Woodworking and housing: positive trends and actions. FDMC. 2016;30(9):52-4,56.

25. Bumgardner M, Buehlmann U. To what do firms attribute success? An application of attribution theory to the secondary woodworking industry. Wood Fiber Sci. 2015;47(1):44-9.

26. Esteves BM, Pereira HM. Wood modification by heat treatment: a review. Bioresources. 2009;4(1):370-404.

27. Espinoza O, Buehlmann U, Laguarda-Mallo MF. Thermally modified wood: marketing strategies of U.S. producers. Bioresources. 2015;10(4):6942-52. This paper provides results and discussion of depth interviews with manufacturers and distributors of thermally modified wood products. The qualitative nature of the paper provided details of this emerging market, including uses for specific hardwood species.

28. Leitch MA. Hardness values for thermally modified treated black ash. Wood Fiber Sci. 2009;41(4):440-6.

29. Hill CAS. Wood modification: an update. Bioresources. 2011;6(2): 918-9.

30. Mallo MFL, Espinoza O. Outlook for cross-laminated timber in the United States. Bioresources. 2014;9(4):7427-43.

31. Crespell P, Gagnon S. Cross laminated timber: a primer. Special publication 52. FP Innovation, 2010, 24 pp.

32. Grasser KK. Development of cross laminated timber in the United States of America. Master's Thesis, University of Tennessee, 2015, $115 \mathrm{pp}$.

33. Mohamadzadeh M, Hindman D. Mechanical performance of yellow-poplar cross laminated timber. Report No. CE/VPI-ST-1513. Virginia Tech, 2015, 29 pp.

34. Slavid R. Endless stair. Nick Watts Design and the American Hardwood Export Council, 2013, 51 pp.

35. Mohammad M, Gagnon S, Douglas BK, Podesto L. Introduction to cross laminated timber. Wood Design Focus. 2012;22(2):3-12.

36. Espinoza O, Buehlmann U, Mallo MFL, Trujillo VR. Identification of research areas to advance the adoption of cross-laminated timber in North America. BioProducts Business. 2016;1(5):60-72.

37. Wherry G, Buehlmann U. Product life cycle of the manufactured home industry. Bioresources. 2014;9(4):6652-68.

38. Vogel-Heuser B, Hess D. Industry 4.0 - prerequisites and visions (guest editorial). IEEE Trans Autom Sci Eng. 2016;13(2):411-3.

39. Gilchrist A. Industry 4.0: the industrial internet of things. Apress, 2016, 250 pp. 
40. Almada-Lobo F. The industry 4.0 revolution and the future of manufacturing execution systems (MES). Journal of Innovation Management (JIM). 2016;3(4):16-21.

41. Foresight. The future of manufacturing: a new era of opportunity and challenge for the UK project report. The Government Office for Science, London, 2013, 248 pp.

42. Hardwood Market Report. The changing landscape of hardwood markets and its impact on sawmill production. Hardwood Market Executive. 2016;10(11):1-8.
43. Geissbauer R, Vedso J, Schrauf S. A strategist's guide to Industry 4.0. strategy+business. 2016;Summer(83):unnumb. Retrieved from http://www.strategy-business.com/article/A-Strategists-Guide-toIndustry-4.0? gko= $7 \mathrm{c} 4 \mathrm{cf}$

44. Thomas RE. Predicting internal yellow-poplar log defect features using surface indicators. Wood Fiber Sci. 2008;40(1):14-22.

45. Cai Z, Ross RJ. Mechanical properties of wood-based composite materials. In: Wood handbook: wood as an engineering material, 2010 Edition. Forest Products Society, 2011, p. 12-1-12. 